\title{
Perception of Parenting Based Training by Android Assisted for BKB Cadre in Demak
}

\author{
Suemi $^{1}$, Joko widodo ${ }^{2}$, Samsudi $^{3}$, Suwito $^{3}$ \\ ${ }^{1,2,3,4}$ Graduate School, Universitas Negeri Semarang, Indonesia \\ ${ }^{1}$ Coresponding email: emygunungpati@gmail.com
}

\begin{abstract}
Bina Keluarga Balita (hereafter BKB) Cadres needs training to improve their skills. Cadre of BKB is community cadre working voluntary in building and giving information to the toddler' parents about how to take care and educate toddlers well. There is still few cadres of $B K B$ getting training so parent's and other family cadres' knowledge and skill in educating toddlers' growth and development through physical stimulation, intelligence motoric, emotional and social economic is lack. Training model accepted by cadre of $B K B$ is still conventional so that it needs innovation in training management for cadre of $B K B$. Material analysis delivered is only children growth and development; there is no correct parenting for children in order that they develop their psychology well. It is a research and development study. The setting of research is Demak Regency. Cadre of $B K B$ is object of the study. The perception of the implementation of $B K B$ cadre parenting based training with android help them to learn material anytime, the knowledge is enriched, and more effective for all education level of the cadre because it is easy to use.
\end{abstract}

Keywords: Parenting, Training, Android, $B K B$ cadre.

\section{Introduction}

Training is an effort to develop human resource especially to develop human intellectual and personality (Basri \& Saebani., 2015). The importance of training is explained by Mustofa Kamil, training is delivering learning and practice, developing to directed purpose, preparing, practicing. Further, he states that training is usually socialized on preparing someone to perform a role or duty, usually in working environment. Therefore, training concept can be applied when there is a number of skill need to be mastered, training is needed to master the skill, little emphasis on theory.

$B K B$ Program needs qualified cadre to give material to the mothers. The cadre needs to get training. Training is believed to improve cadre's ability. Through training given to cadre of $B K B$ the cadre's competency improves, more skilful, more knowledge given to mothers. $B K B$ program is a program of the government to build family to achieve optimal baby growth and development (tentangkb.wordpress.com). $B K B$ program is integral part of national effort to achieve intact Indonesian human, the program is coordinated by Kantor Menteri Urusan Peranan Wanita (The Office of Minister for The Role of Women), the board responsible of the program is Badan Koordonasi Keluarga Berencana Nasional (The National Family Planning Coordination Board) and got grant from
UNICEF (Patmonodewo, 2003). BKB program relates to Posyandu (Integrated Service Post) which uses parenting (mother) education approach, which is an education aimed to mother to introduce attitude and ethic in educating their children.

Training for cadre of $B K B$ is very important, because cadre of $\mathrm{BKB}$ is the community cadre working voluntary to build and give information for parents about how to take care and educate their children well and correctly. The program of $B K B$ aims to improve parents' and other family cadres' knowledge and skill to build the growth and development of their children by physical stimulus, intelligence motoric, emotional and social economy well. Process of the training should use proper approaches to deliver the material. Parenting refers to teaching learning activity focusing on warmth not a onedirection education or without emotion (Megawangi, 2007). Finally, parenting or nursing is everything including what should do by parents to perform their duty and responsible toward the children growth (Hidayati L, 2010). In addition, the parents' duty grows greater more than fulfilling physical needs and give the best for children material, fulfilling children emotional and psychological needs, and giving opportunity to study best. In parenting, the way parents educate their children is the scope of the 
discussion because educating is work and big responsibility for parents (Al-Qahthani, 2013).

Learning using mobile phone is a learning model using sophisticated cellular phone, phalet, tablets, laptop and learning tools of elearning. Mobile learning is more flexible than e-learning because learners may learn wherever and whenever. Mobile Learning (mlearning) is part of electronic learning or known as e-learning (Georgiev, 2005). Mobile learning principally aims to make learners easy to learn everywhere and along tome based on their spare time (Wilson, 2013). Mobile learning is a new learning method maximizing the use of information technology tools, mobile or smartphone. Developing media of mobile learning must be done as interesting as possible to motivate students. Smartphone works based on operational system, such as Android, iOS, Windows Phone, etc (Aripurnamayana, 2012). The development of cellular phone tools impacts education world. One of the cellular phone tools is known as android. Android is an operational system used in smartphone. It is relevant with the argument (Purwantoro \& Achmad, 2001) stating that android is a software used in mobile device to make application use easier. Android can be used as alternative in learning process due to it can perform learning wherever and whenever. The supporting ideas states (Purbasari, 2013) that a supplement alternative for learning is giving chance for students to learn by themselves anytime and everywhere.

\section{Method}

Approach used in the study is qualitative which does not use counting; it is termed as scientific study emphasizing the scientific character of the data source.

The study describes the parenting based training for cadre of $B K B$ using Android. The study is conducted in $B K B$ Demak regency. Data of the study are collected by interview with the cadre of $B K B$, filling questionnaire and document by textbook analysis, note and archive.

\section{Result and Discussion}

The existence of m-learning cannot replace either e-learning (electronic learning) or common learning which is face to face in classroom.

M-learning is aimed to supplement learning existed to give opportunity for students to relearn material which they do not understand without limitation of time and place. It provides new different experience in learning process for the training participants. Based on the field study about the use of android as tools assisting parenting based training for $B K B$ cadre creates many perceptions. The training is inserted in android to make the cadre easy to learn training materials. Based on the interview with $30 B K B$ cadres in Demak regency shows result that the use of android application in training is as follows:

Table 1. Result of the Use of Android

\begin{tabular}{ll}
\hline Percentage & Explanation \\
\hline $\mathbf{5 7 \%}(17$ people $)$ & Absolutely agree \\
$\mathbf{2 6 \%}(\mathbf{8}$ people $)$ & Agree \\
$\mathbf{1 0 \%}(3$ people $)$ & Not really agree \\
$\mathbf{6 . 7 \%}(2$ people $)$ & Not agree \\
\hline
\end{tabular}

It shows in table 1 that 17 people or $57 \%$ state greatly agree by cadre parenting based training of $B K B$ by android assisted. It is due to they regard that by using application in android make them easy to access material or video through the application. They can learn whenever and wherever repeatedly until they understand it. There are 8 people or $26 \%$ states that they agree with the use of application. There are 3 people or $10 \%$ states not really agree and 2 people or $6.7 \%$ do not agree on the use of application because not all cadre having sophisticated smartphone. Few cadre have enough economy level to buy the facility either smartphone or data internet. Cadres also have different education level so that they use the application and understand the material differently, influencing the reliable result achieved through training.

There are several things to attend when using android application in a training, namely a) the use of application used, we must know the function so we can use it well. Without knowledge of how to use the application, we are confused and cannot understand the learning material well. The purpose which can be achieved easily if we understand the application well, is not achieved and it is only time consuming. b) the way to operate the application, the very important thing in operating the application is the way to operate the application to use. A learning material can be easily understood when it is delivered 
through media, it would be difficult to understand if the instructor do not master how to operate the media or application. Therefore, we must understand the way to use the application used in order that the media would be effective and efficient. c) the strength and weakness of the application used must be known by those who would use the application in training in order that the training is effective and can decrease the negative impact of the application used. d) easy or not the application used, learning media in a good training is that the media can be operated easily so we are not confused and no time consuming. Since many application or learning media are difficult to operate. It disturbs learning and learning purpose. Therefore, we have to know whether the application can be operated easily or not. d) Effective and efficient or not the application used, we have to choose the media supporting effective and efficient learning. When learning is effective and efficient, the learning purpose can be achieved and learners can understand the material given faster. Thus, before using application in learning we have to know first whether the application used is effective and efficient.

\section{Conclusion}

The implementation of parenting based training for $B K B$ android assisted is very easy to use. Cadres regards using android application can make the access material or video easy through the application. They can learn whenever and wherever repeatedly until they understand the material. By using application in training we know everything we should know before apply it, such as, the strength and weakness of the application used; and the easiness or difficulty of the application used or not, operated or not; the whether it is effective and efficient or not the application used. We should take media to make learning effective and efficient. When learning is effective and efficient, then learning objective will be achieved easily and students will faster understand the material delivered. Thus, before using application in learning, we should know previously whether it is effective and efficient or not to use.

\section{References}

Al-Qahthani, S. i. b. A. b. W. (2013). Panduan Lengkap Tarbiyatul Aulad. Solo: Zamzam.

Aripurnamayana, M. I. (2012). Rancangan dan Pembuatan Mobile Learning.

Berbasis Android (Studi Kasus : Pembelajaran Sejarah SMP Universitas Gunadarma,, Depok

Basri H., R. a., Saebani BA. . (2015). Manajemen Pendidikan dan Pelatihan. Bandung Pustaka Setia.

Georgiev, T., et al. . (2005). A general classification of mobile learning systems. International conference on computer systems and technologipaes.

Hidayati L, H. H., Kumara A.. (2010). Kekurangan Energi Dan Zat Gizi Merupakan Risiko Kejadian Stunted Pada Anak Usia 1-3 Tahun Yang

Tinggal Di Wilayah Kumuh Perkotaan Surakarta. Kesehatan 3(1), 89-104.

Megawangi, R. (2007). Semua Berakar pada Karakter. Jakarta: FE-UI.

Patmonodewo, S. (2003). Pendidikan Anak Prasekolah. Jakarta Rineka Cipta. Purbasari, R. J. (2013. ). Pengembangan Aplikasi Android sebagai Media Pembelajaran Matematika pada Materi Dimensi Tiga untuk Siswa SMA Kelas X. Jurnal Online Universitas Negeri Malang 1(4).

Purwantoro, S., Rahmawati Heni,, \& Achmad., d. T. (2001). Mobile Searching Obyek Wisata

Pekanbaru Menggunakan Location Base Service (LBS) Berbasis Android Jurnal Politeknik Caltex Riau. , 1(2).

Wilson, M. B., D.U. . (2013. ). Mobile learning: endless possibilities for allied health educators. Journal of Diagnostic Medical Sonography, 29, $220-224$ 